\title{
Antifungal activity of selected plant extracts based on an ethnodirected study
}

\author{
Flávia dos Santos Silva ${ }^{1,2}$ (D), Melissa Fontes Landell ${ }^{3}$ (D), Gustavo Vasconcelos Bastos Paulino ${ }^{3}$ (D), \\ Henrique Douglas Melo Coutinho 4 (D) and Ulysses Paulino Albuquerque ${ }^{1,2 *}$ (D)
}

Received: January 3, 2020

Accepted: April 3, 2020

\begin{abstract}
Plants have been reported as used by local populations to treat various infections for a long time, which has directed several pharmacological studies. The main aim of this work was to evaluate three plant selection criteria with better predictive power to detect extracts with antifungal action: (1) medicinal plants that are not used for indications of infection and inflammation; (2) plants with direct citations for inflammation, except for infection; (3) plants with direct citations for inflammation and infection selected quantitatively by Syndromic Importance Value (SIV). We tested the action of 23 hydroethanolic extracts of plants against the fungi Candida albicans, Cryptococcus neoformans, and Cryptococcus gattii and found no differences in the number of active extracts among the different strategies used, but activity quality varied. The extract of Anacardium occidentale presented fungicidal activity against the three analyzed fungi. At least five species - A. occidentale, Myracrodruon urundeuva, Poincianella pyramidalis, Anadenanthera colubrina var. cebil, and Mimosa oftalmocentra - presented fungistatic and fungicidal effects against all strains. Our findings indicate that selecting plants based on popular indications and quantitative prioritization techniques increases the chance of detecting potential antifungal candidates, and that the plants selected by these criteria were more effective against $C$. neoformans.
\end{abstract}

Keywords: antifungal activity, ethnobotany, ethnopharmacology, natural products, local medical systems

\section{Introduction}

One of the great current challenges in the treatment of fungal diseases has been the resistance they have acquired to certain compounds. This required the use of new drugs for the treatment of infectious diseases caused by these microorganisms (Bastos et al. 2011; Newman \& Cragg 2016). The use of natural products has been an important source in the discovery of new drugs in this area (Newman \& Cragg 2016; Biasi-Garbin et al. 2016). The use of plants by local populations in the treatment of infectious diseases, such as those caused by fungi have been recorded by several studies

1 Programa de Pós-graduação em Etnobiologia e Conservação da Natureza, Departamento de Biologia, Universidade Federal Rural de Pernambuco, 52171-900, Recife, PE, Brazil

2 Laboratório de Ecologia e Evolução de Sistemas Socioecológicos. Departamento de Botânica, Universidade Federal de Pernambuco, 50670-901, Recife, PE, Brazil

3 Instituto de Ciências Biológicas e da Saúde, Universidade Federal de Alagoas, 57072-900, Maceió, AL, Brazil

4 Departamento de Química Biológica, Universidade Regional do Cariri, 63100-000, Crato, CE, Brazil

* Corresponding author: upa677@hotmail.com 
(Maregesi et al. 2008; Svetaz et al. 2010; Bastos et al. 2011; Violante et al. 2012) and has been used to direct research.

The set of approaches based on local knowledge (popular, folk, etc.) has been termed ethnodirected and has guided many studies (Braga et al. 2007; Silva et al. 2013). One of the great challenges in the area, in spite of people's knowledge about medicinal plants, is to find good criteria for prioritizing plants for studies. For example, some studies have evaluated the antimicrobial activity of crude plant extracts popularly used for infections (Maregesi et al. 2008; Violante et al. 2012), injuries (Mølgaard et al. 2011), and inflammations (Braga et al. 2007). Testing the in vitro activity of plants for indications related to infectious diseases and inflammations may be an interesting criterion in the search of plants with antifungal action, since some studies suggest that the information obtained locally are not always clear regarding diseases caused by microorganisms (FerreiraJúnior et al. 2011).

This study aimed to verify the antifungal activity of medicinal plants collected in the area of Caatinga (dry seasonal forest) that were selected based on different criteria within the ethnodirected approach. We used as reference the Minimum Inhibitory Concentration (MIC) of plant extracts against Candida albicans, Cryptococcus neoformans, and Cryptococcus gattii to test the best selection criteria. These fungi were selected as a model due to their clinical relevance. The species $C$. albicans is the most common agent of candidiasis. This disease has been shown to be very resistant in HIV-positive (Rex et al. 2000; Colombo et al. 2013) or immunocompromised patients. Infections caused by $C$. neoformans are generally associated with immunosuppressed individuals (Lin 2009; Ahmed et al. 2014) and C. gattii is very common in immunocompetent individuals (Kwon-Chung et al. 2014).

\section{Materials and methods}

\section{Data treatment and plant selection}

Plants were selected from an ethnobotanical survey executed in a rural community located in the municipality of Altinho, Pernambuco, in northeastern Brazil (Silva et al. 2011) and constitute a database of the Laboratório de Ecologia e Evolução de Sistemas Socioecológicos da Universidade Federal de Pernambuco. We selected the plants based on three groups: $1^{\text {st }}$ Group: medicinal plants that are not used for indications of infections and inflammations; $2^{\text {nd }}$ Group: plants with direct citations for inflammation, but not infections; $3^{\text {rd }}$ Group: plants with direct citations on inflammations and infections. We randomly selected 10 plant species for the first two groups using BioEstat 5.3 software (Ayres et al. 2007). We reviewed the scientific names of all the medicinal plants using the following databases: The Plant List (TPL) (http://www.theplantlist.org/2013), The International Plant Names Index (PNI) (www.ipni.org/ ipni/authorsearchpage.do), and the list of species of Flora do Brasil 2020 online (floradobrasil.jbrj.gov.br).

The plants of the $3^{\text {rd }}$ group were selected based on the Syndromic Importance Value (SIV). The SIV considers the diversity of symptoms cited for each plant, the number of citations attributed by different sources, and the relative importance of each symptom for which the plant was cited (Leduc et al. 2006; Araújo et al. 2008). The calculation of the SIV is given by the following formula:

$$
\mathrm{SIV}=\frac{\left(\sum \mathrm{pxs}\right)+\frac{\left(\sum \mathrm{pxf}\right)}{\mathrm{F}}}{2}
$$

Where $p$ refers to the weight of each indication; $f=$ number of citations for the referred species; $F=$ total number of informants; and $s$ is the total of local symptoms for each species.

The weight of the indications was attributed based on the degree of association of the indication with the mentioned activities. For this, a literature search was performed on the signs and symptoms associated with microbial infections. The weights of the indications ranged from 0.25 to 1.0, where 1 was given for a highly associated indication; 0.75 for those that are moderately associated; 0.5 poorly associated, and 0.25 weakly associated (Tab. 1). The classification of the symptoms for the plants with direct citations, such as anti-inflammatory, was made based on information obtained from the works of Ferreira-Júnior et al. (2011) and Araújo et al. (2008).

Table 1. Weighted (p) values attributed to each anti-microbial and anti-inflammatory indication attributed to the plants cited in the free list performed in a rural community located in an area of Caatinga, Pernambuco, Brazil.

\begin{tabular}{|c|c|c|c|c|c|c|}
\hline Citation & Therapeutic indication (s) \\
\hline $\begin{array}{c}\text { Direct (inflammation and infection) - } \\
\text { moderately associated }\end{array}$ & $\begin{array}{c}\text { Gastritis, ulcer, burn, inflammation, inflammation of the bladder, inflammation of the } \\
\text { tooth, "woman's inflammation/woman's remedy", inflammation of the feet, sore throat, } \\
\text { ovarian inflammation, renal inflammation, urethritis, inflammation of the bladder, urinary } \\
\text { inflammation, vaginal inflammation, inflamed wound, inflammation in the uterus, } \\
\text { tuberculosis, hepatitis, urinary tract infection, anti-inflammatory, bronchitis, infection. }\end{array}$ & 0.75 \\
\hline $\begin{array}{c}\text { Indirect (inflammation and infection) - } \\
\text { poorly associated }\end{array}$ & $\begin{array}{c}\text { Swollen leg, swollen foot, toothache, uterine conditions, rheumatism, thrush, } \\
\text { swelling, mouth ulcer, "woman problems", vaginal discharge. }\end{array}$ \\
\hline $\begin{array}{c}\text { Indirect (inflammation and infection) - } \\
\text { weakly associated }\end{array}$ & $\begin{array}{c}\text { Pain, cut, healing, urinary incontinence, injury, burning, problems in the urethra, } \\
\text { hematoma, diarrhea, renal conditions, itchy rectum, leg pain, expectorant. }\end{array}$ & 0.5
\end{tabular}




\section{Preparation of extracts}

The plant material was collected in an area of Caatinga, located in the municipality of Altinho (Pernambuco, NE Brazil). The exsiccates of the collected plants were identified by experts and deposited in the herbaria of the Instituto Agronômico de Pernambuco (IPA).

The plant material (parts of plants used medicinally, as indicated in the database) was collected from at least three individuals of each species and shade dried at room temperature. The extracts were obtained from $30 \mathrm{~g}$ of the material that was macerated in hydroalcoholic solvent (70 \% ethanol) at room temperature and protected from light. Successive extractions were performed until complete extraction of the plant material. The first one was performed after 48 hours and the others at 24-hour intervals. After this period, the solvent was removed using the rotary evaporator at a temperature of $40{ }^{\circ} \mathrm{C}$. The obtained extract was placed in a desiccator.

\section{Minimum inhibitory concentration test (MIC)}

The extracts were tested against $C$. albicans (ATCC 90028), C. neoformans (ATCC 40283), and C. gattii (ATCC 56990) obtained from the Laboratório de Diversidade Molecular da Universidade Federal de Alagoas (UFAL).

In vitro susceptibility of yeast isolates was performed using broth microdilutions according to the methodology recommended by the Clinical and Laboratory Standards Institute - CLSI in M27-A3 protocol (2008). The strains were previously cultured on YEPD agar medium ( $2 \%$ glucose, $0.5 \%$ yeasts extract, $0.5 \%$ peptone, $2 \%$ agar) at $35^{\circ} \mathrm{C}$ for $48 \mathrm{~h}$ to be metabolically active for the tests. An inoculum was prepared by suspension of colonies in saline solution $(0.85 \%)$, and the cell density was spectrophotometrically fixed according to an absorbance turbidity equivalent to that of a $0.5 \mathrm{McF}$ arland $\left(\sim 1 \times 10^{6}\right.$ a $5 \times 10^{6}$ cells $\left./ \mathrm{mL}\right)$. The crude extracts were resuspended in dimethyl sulfoxide (DMSO) in a ratio of 1:1. The concentration tested ranged from 20 to $0.0391 \mu \mathrm{g} / \mu \mathrm{L}$, but when necessary, the range was increased from 0.0003 to $20 \mu \mathrm{g} / \mu \mathrm{l}$. The microdilution plates containing RPMI-1640 (RPMI tissue culture medium supplemented with glutamine) buffered to $\mathrm{pH} 7.0$ using 0.156 M 3-N-morpholinopropane-sulphonic acid (MOPS) with different concentrations of extracts, were inoculated with $100 \mu \mathrm{L}$ of diluted culture, resulting in $0.5 \times 10^{3}$ to $2.5 \mathrm{x}$ $10^{3}$ cells $/ \mathrm{mL}$ in each well (total of $200 \mu \mathrm{L}$ ), as recommended by the CLSI broth microdilution method. Following this, the plates were incubated at $35^{\circ} \mathrm{C}$ for $24-48 \mathrm{~h}$. The positive control was composed of culture medium and yeast, and the negative control contained DMSO in the concentration used to dilute the extracts. As antifungal control, we used two agents of different classes: Amphotericin B and fluconazole, with the concentrations tested ranging from 16 to $0.0313 \mu \mathrm{g} / \mathrm{mL}$ and 64 to $0.125 \mu \mathrm{g} / \mu \mathrm{L}$, respectively, according to Khyriem et al. (2006) and the CLSI manual.
The minimal inhibitory concentrations were determined as the minimal compound concentration at which no visible growth (100\% of inhibition) was observed when compared to the control (wells without any antifungal agents). For determining whether the extracts used present fungicidal or fungistatic activity, a small volume $(5 \mu \mathrm{L})$ of each of the wells with no apparent yeast growth were inoculated in YEPD agar medium and incubated at $35^{\circ} \mathrm{C}$ for 48 hours. To avoid antifungal carryover, aliquots were deposited as a spot onto the agar plate and allowed to soak. The result was obtained according to the formation, or not, of colonies at the inoculated site. These were included as control strains in each set of experiments.

\section{Data analysis}

Through the demonstrated activities of the plants, the three selection criteria were compared for the number of active extracts using the $G$ test (considering $p<0.05$ ).

\section{Results and discussion}

Among the 30 plants selected for the three groups of criteria mentioned, only 23 were tested due to difficulties in availability, since the Caatinga environment presents a strong seasonality, which limits the temporal supply of plant material to few months of the year (Tab. 2).

According to the value of the SIV, eight species were indicated as priority (see Tab. 3 ). The species that were calculated to possess the highest weight were $M$. urundeuva and A. colubrina. Both had a higher frequency of citation and weight of the symptoms compared to those of the other species.

There were no significant differences $(G=2.9503 ; \mathrm{p}=0.566)$ among the selection criteria in relation to the number of active extracts for each evaluated strain, indicating that the amount of active extracts does not seem to depend on the technique of selection used. Although the number of active extracts did not differ with respect to the selection criteria, it was possible to observe divergence among them with respect to the degree of inhibitory activity and the number of strains susceptible to the extracts. For example, plants cited as anti-inflammatory and selected by SIV were seen to be more effective against $C$. neoformans alone.

The proportion of active plants has demonstrated the relevance of the ethnodirected approaches to test the in vitro activity of crude vegetal extracts against fungi. Studies have confirmed that plants which are reported to be used by local populations have higher antimicrobial potential than those which are selected by other approaches, such as random selection. For example, Svetaz et al. (2010) found that the probability of finding plants with anti-fungal properties was higher in those with ethnomedical uses related to fungal infections compared to those that were randomly selected. Besides that, strong activity (MIC $\leq 1000 \mu \mathrm{g} / \mathrm{mL}$ ) against dermatophytes was found in the group of plants selected through the ethnodirected approach. 
Table 2. Plant species selected based on different selection criteria for antifungal evaluation.

\begin{tabular}{|c|c|c|c|}
\hline Family / Species / Voucher & Plant & Part & Indication \\
\hline \multicolumn{4}{|c|}{ 1st Group: Randomly Selected-Plants without indications for inflammation and infection } \\
\hline Apocynaceae/ Catharanthus roseus (L.) Don/ IPA 91036 & boa noite & flower, leaf & insomnia, malaria \\
\hline Asclepiadaceae/Calotropis procera (Aiton) W.T.Aiton/ IPA 91035 & algodão de seda & leaf & headache \\
\hline Lamiaceae/ Ocimum campechianum Mill. & alfavaca & Entire plant & analgesic \\
\hline Malpighiaceae/ Stigmaphyllon auriculatum (Cav.) A.Juss./ IPA 91037 & louco & leaf & allergy, wart \\
\hline Myrtaceae/ Eugenia punicifolia (Kunth) DC./ IPA 91051 & pirim & bark & worms \\
\hline Myrtaceae/ Eugenia pyriformis Cambess. & ubaia & bark & stomachache \\
\hline Solanaceae/ Nicotiana glauca Graham/ IPA 91033 & pára raio & leaf & headache \\
\hline \multicolumn{4}{|c|}{ 2nd Group: Randomly selected - Plants with indications for inflammation } \\
\hline Capparaceae/Tarenaya spinosa (Jacq.) Raf./ IPA 91045 & mussambê & flower & bronchitis \\
\hline Lythraceae/ Punica granatum L./ IPA 91046 & romã & peel of the fruit & inflamed tooth \\
\hline Anacardiaceae/Schinopsis brasiliensis Engl./ IPA 91044 & braúna & bark & inflammation, tooth inflammation \\
\hline Capparaceae/Crateva tapia L./ IPA 91056 & trapiá & bark & inflammation of the urethra \\
\hline Leguminosae-Caesalpinioideae/Bauhinia cheilantha Steud./ IPA 91040 & mororó & leaf & gastritis \\
\hline Leguminosae-Caesalpinioideae/Libidibia ferrea (Mart. ex Tul.) L.P.Queiroz/ IPA 91057 & jucá & bark & gastritis \\
\hline Meliaceae/Cedrela odorata L. & cedro & bark & inflammation and sinusitis \\
\hline Rubiaceae/Coutarea hexandra (Jacq.) K. Schum. & quina- quina & bark & inflammation and sinusitis \\
\hline \multicolumn{4}{|c|}{ 3rd Group: SIV- Plants with indications for inflammation and infection } \\
\hline Anacardiaceae/Anacardium occidentale L./ IPA 90995 & cajú roxo & bark & $\begin{array}{l}\text { kidney conditions, inflamed tooth, infection, inflammation, “woman's } \\
\text { inflammation", sore throat }\end{array}$ \\
\hline Anacardiaceae/Myracrodruon urundeuva Allemão/ IPA 91068 & aroeira & bark & $\begin{array}{l}\text { kidney conditions, uterine conditions, wound, dental pain, leg pain, gastritis, } \\
\text { infections, urinary infection, inflammation, tooth inflammation, } \\
\text { "woman's inflammation", sore throat, uterine inflammation, } \\
\text { swollen foot, "women problems", burn, }\end{array}$ \\
\hline Capparaceae/Cynophalla hastata (Jacq.) J.Presl/ IPA 91063 & pau-d'arco roxo & bark & $\begin{array}{l}\text { uterine conditions, wound, inflammation, } \\
\text { uterine inflammation, tuberculosis }\end{array}$ \\
\hline Celastraceae/Maytenus rigida Mart./ PEUFR 46182 & bom nome & bark & $\begin{array}{l}\text { kidney conditions, vaginal discharge, wound, gastritis, } \\
\text { hematoma, infection, kidney inflammation, urethritis }\end{array}$ \\
\hline Leguminosae-Caesalpinioideae/Poincianella pyramidalis (Tul.) L.P.Queiroz/IPA 91043 & catingueira & bark & $\begin{array}{c}\text { gastritis, hepatitis, swelling, urinary infection, } \\
\text { diarrhea, rheumatism }\end{array}$ \\
\hline Leguminosae-Mimosoideae/Anadenanthera colubrina var. cebil (Griseb.) Altschul/ IPA 91059 & angico & bark & $\begin{array}{l}\text { kidney conditions, uterine conditions, bronchitis, inflammation, } \\
\text { "woman's remedy", tuberculosis, wound }\end{array}$ \\
\hline Leguminosae-Mimosoideae/Mimosa oftalmocentra Mart. ex Benth./ IPA 91054 & jurema preta & bark & $\begin{array}{l}\text { uterine conditions, wound, gastritis, infection, } \\
\text { inflammation, foot inflammation }\end{array}$ \\
\hline Rhamnaceae/Ziziphus joazeiro Mart. / IPA 91058 & juá & bark & expectorant, flu, tuberculosis \\
\hline
\end{tabular}


The plants used for indications of infections and inflammation showed interesting results against the analyzed fungi. We found that studies have previously selected plants based on these indications and have observed anti-microbial or anti-fungal properties in these plants. A study implemented in Chile has verified the antifungal action of plants which were used for injuries and associated infections against Penicillium expansum and C. albicans. Among the 40 evaluated species, 30 presented interesting antimicrobial activities, corroborating with their traditional uses (Silva et al. 2013). Braga et al. (2007) selected plants traditionally used in infectious diseases and inflammation and evaluated their activity against fungi. Among the 24 methanolic extracts obtained from 20 plants, only those of Schinus terebintifolius, O. gratissimum, Cajanus cajan, and Piper aduncum, with MIC of $1.25 \mathrm{mg} / \mathrm{ml}$, presented activity against $C$. albicans. In contrast, the species Bixa Orellana, O. gratissimum and Syzygium cumini with MIC of $0.078 \mathrm{mg} /$ $\mathrm{ml}$, presented better activity against $C$. neoformans. The proportion of species with interesting activities has been lower than that observed in our studies. However, the definition of the criteria has been important in the attempt to reduce efforts and costs with in vitro tests.

From the total number of extracts evaluated (23), ten extracts showed activity against $C$. albicans, 21 (91\%) against the fungus $C$. neoformans, which was the most sensitive to the evaluated extracts, and $14(60 \%)$ showed activity against C. gattii. The inhibitory activity of the extracts against $C$. gattii was verified if the extracts exhibited activity against C. albicans and C. neoformans. Among all the extracts tested, $48 \%$ presented weak fungicidal and fungistatic activity against at least one strain, with MIC varying between 0.039 and $20 \mu \mathrm{g} / \mu \mathrm{l}$. Of the plants prioritized by the SIV, only five (A. occidentale, M. urundeuva, P. pyramidalis, A. colubrina var. cebil, and M. oftalmocentra) presented antifungal effects against all three strains (C. albicans, $C$. neoformans, and $C$. gattii), with MIC ranging from 0.0049 to $20 \mu \mathrm{g} / \mu \mathrm{l}$ (Tab. 4). The extracts that showed strong inhibitory activity were A. occidentale bark extract for $C$. neoformans, compared to fluconazole, and extracts of $M$. urundeuva and P. pyramidalis, compared to amphotericin B, against the same strain (Tab. 4).

Among the eight randomly selected plants with citations for use in inflammation, extracts of L. ferrea, S. brasiliensis, and P. granatum showed fungicidal action against all strains, with MIC between 0.0049 and $1.25 \mu \mathrm{g} / \mu \mathrm{l}$. The extract from the bark of $S$. brasiliensis showed strong fungicidal activity for C. neoformans (MIC $0.0049 \mu \mathrm{g} / \mu \mathrm{l}$ ) compared to fluconazole. Among the seven medicinal plants randomly selected (used in cases without indications of inflammation and infection), only E. pyriformis extract showed fungistatic activity against $C$. albicans (MIC $5 \mu \mathrm{g} / \mu \mathrm{l}$ ) and fungicidal activity against $C$. gattii (MIC $20 \mu \mathrm{g} / \mu \mathrm{l}$ ) and $C$. neoformans (MIC of $0.009 \mu \mathrm{g} / \mu \mathrm{l}$ ) with a good inhibitory effect. The hydroalcoholic extracts from $B$. cheilantha and C. tapia were the only ones considered inactive against the three strains (Tab. 4). However, for this same selection category, most of the extracts reported were inactive against only $C$. albicans (Tab. 4).

A previous study (Cruz et al. 2007) evaluated the activity of $Z$. joazeiro, Caesalpinia pyramidalis (valid name: Poincianella pyramidalis), Bumelia sartorum (valid name: Sideroxylon obtusifolium), and Hymenaea courbaril, which are plants popularly known for their treatment of mycoses, against $C$. albicans, $C$. guilliermondii, $C$. neoformans, and Trichophyton rubrum. Of these, only the aqueous extracts obtained from the leaves of $C$. pyramidalis and from the bark of $Z$. joazeiro were effective (MIC of $6.5 \mu \mathrm{g} / \mathrm{mL}$ ) against the fungi $C$. guilliermondii and T. rubrum. Similar to our results, $Z$. joazeiro showed substantial activity against $C$. neoformans. However, no activity was reported against $C$. albicans and $Z$. joazeiro presented the best activity in the study carried out by Cruz et al. (2007). Finding plants with antifungal potential has not been easy (Souza 2010), because even when such activity is observed, many other substances present a high level of toxicity. Due to this complexity concerning the bioprospecting of plants with antifungal activity, our data show that the use of direct citations for infections and inflammations may be a good tool in the search of potential antifungal candidates, since medicinal plants without these indications did not present better activity.

\section{Data availability}

The data used to support the findings of this study are included within the article and can be solicited by request to the authors.

Table 3. Syndromic Importance Value (SIV) of plants used in cases of inflammation and infections in the area of Caatinga, Northeast Brazil.

\begin{tabular}{|c|c|c|c|c|}
\hline Species & S & $f$ & p & SIV \\
\hline Myracrodruon urundeuva Allemão & 20 & 77 & 11.25 & 117 \\
\hline Anadenanthera colubrina var. cebil (Griseb.) Altschul & 19 & 24 & 11.25 \\
\hline Maytenus rigida Mart. & 9 & 38 & 5 & 108 \\
\hline Mimosa oftalmocentra Mart. ex Benth. & 7 & 23 & 3.75 & 14 \\
\hline Anacardium occidentale L. & 5 & 34 & 3 & 8 \\
\hline Cynophalla hastata (Jacq.) J.Presl & 5 & 10 & 3 & 7.6 \\
\hline Ziziphus joazeiro Mart. & 3 & 43 & 1.25 & 4.3 \\
\hline Poincianella pyramidalis (Tul.) L.P. Queiroz & 2 & 27 & 1.5 & 1.7 \\
\hline
\end{tabular}

Note: s: total local symptoms for each species; $f$ : number of citations for the cited species; p: weight of each indication; SIV: Syndromic Importance Value. 
Table 4. Determination of Minimum Inhibitory Concentration $(\mu \mathrm{g} / \mu \mathrm{l})$ of the selected plant extracts by different criteria through the ethnodirected approach.

\begin{tabular}{|c|c|c|c|c|}
\hline \multirow{2}{*}{ Species } & \multirow{2}{*}{ Part } & \multicolumn{3}{|c|}{ Microorganisms } \\
\hline & & $\mathrm{Ca}$ & $\mathrm{Cn}$ & $\mathrm{Cg}$ \\
\hline \multicolumn{5}{|c|}{$3^{\text {rd }}$ Group: SIV - Plants with indications for inflammation and infections } \\
\hline Anacardiaceae/Anacardium occidentale L. & B & $0.312^{*}$ & $0.0049^{*}$ & $0.039^{*}$ \\
\hline Anacardiaceae/ Myracrodruon urundeuva Allemão & B & $0.156^{* *}$ & $0.0024^{*}$ & $0.019^{*}$ \\
\hline Capparaceae/Cynophalla hastata (Jacq.) J.Presl & B & N/A & $1.25^{* *}$ & $\mathrm{~N} / \mathrm{T}$ \\
\hline Celastraceae/ Maytenus rigida Mart. & B & N/A & $1.25^{* *}$ & $\mathrm{~N} / \mathrm{T}$ \\
\hline Leguminosae-Caesalpinioideae/ Poincianella pyramidalis (Tul.) L.P.Queiroz & B & $5^{* *}$ & $0.0024^{*}$ & $0.019^{*}$ \\
\hline Leguminosae-Mimosoideae/Anadenanthera colubrina var. cebil (Griseb.) Altschul & B & $20^{*}$ & $0.078^{*}$ & $5^{* *}$ \\
\hline Leguminosae-Mimosoideae/ Mimosa oftalmocentra Mart. ex Benth./ IPA 91054 & B & $0.625^{* *}$ & $0.009^{* *}$ & $0.019^{* *}$ \\
\hline Rhamnaceae/Ziziphus joazeiro Mart. & B & N/A & $20^{* *}$ & $\mathrm{~N} / \mathrm{T}$ \\
\hline \multicolumn{5}{|c|}{$2^{\text {nd }}$ Group: Randomly selected - Plants with no indications of inflammation and infection } \\
\hline Apocynaceae/Catharanthus roseus (L.) Don & $\mathrm{Fl}, \mathrm{L}$ & N/A & $5^{* *}$ & $5^{*}$ \\
\hline Asclepiadaceae/Calotropis procera (Aiton) W.T.Aiton & $\mathrm{L}$ & N/A & $10^{* *}$ & $\mathrm{~N} / \mathrm{T}$ \\
\hline Lamiaceae/ Ocimum campechianum Mill. & EP & N/A & $0.039^{*}$ & $2.5^{*}$ \\
\hline Malpighiaceae/Stigmaphyllon auriculatum (Cav.) A. Juss. & $\mathrm{L}$ & N/A & $0.156^{* *}$ & $\mathrm{~N} / \mathrm{T}$ \\
\hline Myrtaceae/Eugenia punicifolia (Kunth) DC. & B & N/A & $0.039^{* *}$ & $0.312^{*}$ \\
\hline Solanaceae/Nicotiana glauca Graham & $\mathrm{L}$ & N/A & $0.312^{* *}$ & $20^{* *}$ \\
\hline Myrtaceae/Eugenia pyriformis Cambess. & B & $5^{* *}$ & $0.009^{*}$ & 20 \\
\hline \multicolumn{5}{|c|}{$1^{\text {st }}$ Group: Randomly selected - Plants with indications for inflammation } \\
\hline Capparaceae/Crateva tapia L. & B & N/A & N/A & $\mathrm{N} / \mathrm{T}$ \\
\hline Lythraceae/ Punica granatum L. & $\mathrm{P}$ & $0.625^{* *}$ & $0.078^{* *}$ & $0.078^{*}$ \\
\hline Meliaceae/Cedrela odorata L. & B & N/A & $0.078^{* *}$ & N/A \\
\hline Capparaceae/Tarenaya spinosa (Jacq.) Raf. & Fl & N/A & $5^{* *}$ & $20^{*}$ \\
\hline Leguminosae-Caesalpinioideae/Libidibia ferrea (Mart. ex Tul.) L.P.Queiroz & B & $1.25^{* *}$ & $0.15^{*}$ & $0.07^{*}$ \\
\hline Leguminosae-Caesalpinioideae/Bauhinia cheilantha Steud. & $\mathrm{L}$ & N/A & N/A & $\mathrm{N} / \mathrm{T}$ \\
\hline Rubiaceae/Coutarea hexandra (Jacq.) K. Schum. & B & $0.039 * *$ & $2.5^{*}$ & N/A \\
\hline Anacardiaceae/Schinopsis brasiliensis Engl. & B & $0.039^{* *}$ & $0.0049^{*}$ & $0.019^{*}$ \\
\hline
\end{tabular}

Microrganisms: Ca=Candida albicans ATCC 90028; Cn=Cryptococcus neoformans ATCC 40283; Cg=Cryptococcus gattii ATCC 56990. Parts of plants: B=bark; L=leaf; Fl=Flower; EP=entire plant; $\mathrm{P}=$ peel. N/A = no activity; N/T = Not tested. ${ }^{*}$ fungicidal; ${ }^{* *}$ fungistatic. Cryptococcus sp. $=$ Amphotericin $\mathrm{B}<0.002 \mu \mathrm{g} / \mu \mathrm{L}$ and fluconazole $<0.008 \mu \mathrm{g} / \mu \mathrm{L}$. C. albicans ATCC $90028=0.00025-0.001 \mu \mathrm{g} / \mu \mathrm{L}$ for fluconazole and $0.0005-0.002 \mu \mathrm{g} / \mu \mathrm{L}$ for Amphotericin B.

\section{Acknowledgements}

To the members of Laboratório de Ecologia e Evolução de Sistemas Socioecológicos da Universidade Federal de Pernambuco and to the Laboratório de Microbiologia e Biologia Molecular da Universidade Regional do Cariri (URCA) for their support. This study was financed in part by the Coordenação de Aperfeiçoamento de Pessoal de Nível Superior - Brasil (CAPES), Finance Code 001, with contributions from the INCT Ethnobiology, Bioprospecting, and Nature Conservation certified by $\mathrm{CNPq}$, and financial support from FACEPE (Grant number: APQ-0562-2.01/17).

\section{References}

Ahmed AS, McGaw LJ, Elgorashi EE, Naidoo V, Eloff JN. 2014. Polarity of extracts and fractions of four Combretum (Combretaceae) species used to treat infections and gastrointestinal disorders in southern African traditional medicine has a major effect on different relevant in vitro activities. Journal of Ethnopharmacology 154: 339-350.

Araújo TAS, Alencar NL, Amorim ELC, Albuquerque UP. 2008. A new approach to study medicinal plants with tannins and flavonoids contents from the local knowledge. Journal of Ethnopharmacology 120: $72-80$.

Ayres M, Ayres MJ, Ayres DL, Santos SA. 2007. BioEstat 5.3: aplicações estatísticas nas áreas das ciências biológicas e médicas. Belém, Sociedade Civil de Mamirauá.

Bastos GM, Nogueira NAP, Soares CL, Martins MR, Rocha LQ, Teixeira AB. 2011. In vitro determination of the antimicrobial potential of homemade preparations based on medicinal plants used to treat infectious diseases. Revista de Ciências Farmacêuticas Básica e Aplicada 32: 113-120.

Biasi-Garbin RP, Demitto FO, Amaral RCR, et al. 2016. Antifungal potential of plant species from Brazilian caatinga against dermatophytes. Revista do Instituto de Medicina Tropical de São Paulo 58: 18. doi: 10.1590/ S1678-9946201658018

Braga FG, Bouzada MLM, Fabri RL, et al. 2007. Antileishmanial and antifungal activity of plants used in traditional medicine in Brazil. Journal of Ethnopharmacology 111: 396-402.

Clinical and Laboratory Standards Institute - CLSI. 2008. Reference Method for Broth Dilution Antifungal Susceptibility Testing of Yeasts; Approved Standard / $3^{\text {rd }}$ ed. CLSI document M27-A3. Philadelphia, Wayne.

Colombo AL, Guimarães T, Camargo LFA, et al. 2013. Brazilian guidelines for the management of candidiasis - a joint meeting report of three medical societies: Sociedade Brasileira de Infectologia, Sociedade Paulista de Infectologia and Sociedade Brasileira de Medicina Tropical. The Brazilian Journal of Infectious Diseases 17: 283-312.

Cruz MCS, Santos PO, Barbosa AM, et al. 2007. Antifungal activity of Brazilian medicinal plants involved in popular treatment of mycoses. Journal of Ethnopharmacology 111: 409-412. 


\section{Flávia dos Santos Silva, Melissa Fontes Landell, Gustavo Vasconcelos Bastos Paulino, Henrique Douglas Melo Coutinho and Ulysses Paulino Albuquerque}

Ferreira-Júnior WS, Ladio AH, Albuquerque UP. 2011. Resilience and adaptation in the use of medicinal plants with suspected antiinflammatory activity in the Brazilian Northeast. Journal of Ethnopharmacology 138: 238-252.

Khyriem AB, Sujatha S, Parija SC. 2006. Antifungal susceptibility of Cryptococcus neoformans to amphotericin B and fluconazole. Indian Journal of Pathology \& Microbiology 49: 307-308.

Kwon-Chung KJ, Fraser JA, Doering TL, et al. 2014. Cryptococcus neoformans and Cryptococcus gattii, the etiologic agents of cryptococcosis. Cold Spring Harbor Perspectives Medicine 4: a019760. doi: 10.1101 / cshperspect.a019760

Leduc C, Coonishish J, Haddad P, Cuerrier A. 2006. Plants used by the Cree Nation of Eeyou Istchee (Quebec, Canada) for the treatment of diabetes: A novel approach in quantitative ethnobotany. Journal of Ethnopharmacology 105: 55-63.

Lin X. 2009. Cryptococcus neoformans: morphogenesis, infection, and evolution. Infection, Genetics and Evolution 9: 401-416.

Maregesi SM, Pieters L, Ngasspa OD, et al. 2008. Screening of some Tanzanian medicinal plants from Bunda district for antibacterial, antifungal and antiviral activities. Journal of Ethnopharmacology 119: 58-66.

Mølgaard P, Holler JG, Asar B, et al. 2011. Antimicrobial evaluation of Huilliche plant medicine used to treat wounds. Journal of Ethnopharmacology 138: 219-227.
Newman DJ, Cragg GM. 2016. Natural products as sources of new drugs from 1981 to 2014. Journal of Natural Products 79: 629-661.

Rex JH, Walsh TJ, Sobel JD, Filler SG, Pappas PG, Dismukes WE, et al. 2000. Practice guidelines for the treatment of candidiasis. Clinical Infectious Diseases 30: 662-678.

Silva ACO, Santana EF, Saraiva AM, et al. 2013. Which approach is more effective in the selection of plants with antimicrobial activity? EvidenceBased Complementary and Alternative Medicine 2013: 308980. doi:10.1155/2013/308980

Silva FS, Ramos MA, Hanazaki N, Albuquerque UP. 2011. Dynamics of traditional knowledge of medicinal plants in a rural community in the Brazilian semi-arid region. Revista Brasileira de Farmacognosia 21: 382-391.

Souza NAB. 2010. Possíveis mecanismos de atividade antifúngica de óleos essenciais contra fungos patogênicos. PhD Thesis. Universidade Federal da Paraíba, João Pessoa.

Svetaz L, Zuljan F, Derita M, et al. 2010. Value of the ethnomedical information for the discovery of plants with antifungal properties. A survey among seven Latin American countries. Journal of Ethnopharmacology 127: 137-158.

Violante IMP, Hamerski L, Garcez WS, et al. 2012. Antimicrobial activity of some medicinal plants from the Cerrado of the central- western region of Brazil. Brazilian Journal of Microbiology 43: 1302-1308. 